\title{
Impact of rural schools on further adaptation of rural youth to the university life in a city: experience of Bohdan Khmelnytsky National University
}

\author{
Yulia Shalivska ${ }^{1}$, Kateryna Tkachenko ${ }^{2}$, Serhiy Danylyuk ${ }^{3}$ \\ ${ }^{1}$ Rivne State University of the Humanities. Department of Theory and Methods of Education. Stepana Bandery Str., 12, Rivne, \\ Ukraine. ${ }^{2}$ Bohdan Khmelnytsky National University at Cherkasy, Ukraine. ${ }^{3}$ Bohdan Khmelnytsky National University at \\ Cherkasy, Ukraine. \\ Author for correspondence: ukr_scientist@ukr.net
}

\begin{abstract}
The current research aims to summarize the features of school education in rural areas in Ukraine and to establish their potential influence on students' academic and socio-psychological adaptation to a new learning and living environment. Small number of students in class, poor material and technical condition, limited opportunities for selfrealization, low motivation to study etc. are distinguished as the basic peculiarities of Ukrainian rural schools. The authors' miniquestionnaire revealed that $62 \%$ of the first-year students of rural origin from a local Bohdan Khmelnytsky National University at Cherkasy experience hardships during adaptation. Challenges faced by 270 first-year students are described: personal, educational, living conditions, psychological, communicative, relationships in the group. The outcomes of the study convince that students of rural origin encounter additional challenges adjusting to changed living conditions while studying in universities in contrast to students from urban and suburban areas. Recommendations are provided to assist rural school counselors in preparing students for their further adaptation at large colleges and universities. Directions of work of psychological service, counsellors and educators in higher education institutions are displayed: individual counseling for the student, development and implementation of special training programs, integration of individual classes into training programs.
\end{abstract}

Keywords: Adaptation, First-Year Student, Higher Education Institution, Rural School, Student of Rural Origin, Ukraine.

\begin{tabular}{l|l|l|l|l|l|l|} 
RBEC & Tocantinópolis/Brasil & v. 5 & e9537 & $10.20873 /$ uft.rbec.e9537 & 2020 & ISSN: 2525-4863 \\
\hline
\end{tabular}




\section{Impacto de las escuelas rurales en una mayor adaptación de los jóvenes rurales a la vida universitaria en la ciudad: la experiencia de la Universidad Nacional Bohdan Khmelnytsky}

RESUMEN. La investigación actual tiene por objeto resumir las características de la educación escolar en las zonas rurales de Ucrania y establecer su posible influencia en la adaptación académica y sociopsicológica de los estudiantes a un nuevo entorno de aprendizaje y de vida. Se distinguen como peculiaridades básicas de las escuelas rurales ucranianas el reducido número de alumnos en las clases, las malas condiciones materiales y técnicas, las limitadas oportunidades de realización personal, la escasa motivación para estudiar, etc. El minicuestionario de los autores reveló que el $62 \%$ de los estudiantes de primer año de origen rural de la Universidad Nacional Bohdan Khmelnytsky de Cherkasy experimentan dificultades durante la adaptación. Se describen los desafíos a los que se enfrentan 270 estudiantes de primer año: personales, educativos, condiciones de vida, psicológicos, comunicativos, relaciones en el grupo. Los resultados del estudio convencen de que los estudiantes de origen rural se enfrentan a dificultades adicionales para adaptarse a las nuevas condiciones de vida mientras estudian en las universidades, en contraste con los estudiantes de las zonas urbanas y suburbanas. Se formulan recomendaciones para ayudar a los consejeros de las escuelas rurales a preparar a los estudiantes para su ulterior adaptación en los grandes colegios y universidades. Se muestran las direcciones de trabajo del servicio psicológico, los consejeros y los educadores en las instituciones de enseñanza superior: asesoramiento individual para el estudiante, desarrollo e implementación de programas de formación especiales, integración de clases individuales en los programas de formación.

Palabras clave: Adaptación, Estudiante de Primer Año, Institución de Educación Superior, Escuela Rural, Estudiante de origen rural, Ucrania. 


\section{Impacto das escolas rurais na adaptação da juventude rural à vida universitária em uma cidade: experiência da Universidade Nacional Bohdan Khmelnytsky}

RESUMO. A pesquisa atual visa resumir as características da educação escolar nas áreas rurais da Ucrânia e estabelecer sua influência potencial na adaptação acadêmica e sócio-psicológica dos estudantes a um novo ambiente de aprendizagem e vida. Um pequeno número de estudantes em sala de aula, más condições materiais e técnicas, oportunidades limitadas de auto-realização, baixa motivação para estudar, etc., distinguem-se como as peculiaridades básicas das escolas rurais ucranianas. O miniquestionário dos autores revelou que $62 \%$ dos estudantes de primeiro ano de origem rural de uma Universidade Nacional Bohdan Khmelnytsky local em Cherkasy experimentam dificuldades durante a adaptação. Os desafios enfrentados por 270 alunos do primeiro ano são descritos: pessoais, educacionais, condições de vida, psicológicas, comunicativas, relacionamentos no grupo. Os resultados do estudo convencem que os estudantes de origem rural enfrentam desafios adicionais de adaptação às condições de vida alteradas enquanto estudam nas universidades, ao contrário dos estudantes de áreas urbanas e suburbanas. São fornecidas recomendações para ajudar os conselheiros das escolas rurais a preparar os estudantes para sua posterior adaptação nas grandes faculdades e universidades. São apresentadas instruções de trabalho de serviço psicológico, conselheiros e educadores em instituições de ensino superior: aconselhamento individual para o estudante, desenvolvimento e implementação de programas especiais de treinamento, integração de aulas individuais em programas de treinamento.

Palavras-chave: Adaptação, Estudante de Primeiro Ano, Instituição de Ensino Superior, Escola Rural, Estudante de Origem Rural, Ucrânia. 


\section{Introduction}

Over 3.4 billion people live in rural or remote areas worldwide (Cole, 2019). 1.2 million Ukrainian children receive secondary education in rural areas, since 19294 schools are in rural areas (Samohin, 2014).

The overall educational attainment of people living in rural areas has increased markedly over time in most countries of the world (Rural Education, 2019). In the United States, in 2015, 29\% of 18-24-year olds from rural areas enrolled in a postsecondary education program and completed higher education (Rural Students in Higher Education, 2020).

This group of young people needs special social and psychological support in the process of their academic, social and emotional adaptation to the urban community, on the grounds that the mere fact of changing one's place of residence and study actualizes mental complexes and can lead to identity crisis or cause a sense of personal incapacity.

Young people who come to get education in a big city, not only adapt to the conditions of the urban environment, but try to integrate into the city community, become a member of this community and bearer of its norms and values. The success of a student's adaptation to the new environment will depend on how adequately or problematically he or she will survive the new social status, rights and obligations, and on how new expectations are provided.

The process of adapting a student to the conditions of a higher education institution is an important stage, since the student is getting acquainted with new forms of activity, communication, leisure, correlates his/her own expectations with reality, his/her attitude to educational activity is formed. The process is accompanied by an adaptation to new living conditions, new social status and environment, another rhythm of learning, acquisition of new skills and experience, special social behavior and psychology (Zdanevych, 2011).

Admission to a higher education institution requires not only hard work aimed at mastering the means of professional activity, but also the restructuring of self-awareness and consciousness in general caused by the new environment of teenagers and grownups, the need for earnings, possible move to another city, accommodation in a hostel and more. Solution of these problems requires internal selforganization, ability to allocate time and strength in the educational regime, awareness and change of life values and prospective plans. 
Studies by Ackermann \& Morrow (2007-2008), Chang et al. (2007) illustrate that there are many students who are not able to finish their studies. According to Elias, Mahyuddin \& Uli (2009), 57\% of those who leave their studies before graduation, are not satisfied with their lives since entering university.

As freshmen arrive at university with different personal, social, cultural and linguistic backgrounds, characteristics and factors that affect the adjustment process necessarily vary from one student to another (p. 64, Al-Mahrooqi, Denman, \& Ateeq, 2015).

The review of the adjustment literature exposes that the students' adaptation process to new learning environment may be complicated by the mismatch of their subjective expectations and the existing reality or by the fact that quite often the choice of profession is determined not by students' own preferences, but by the parents' instructions, which in turn increases the feeling of dissatisfaction.

The adaptation process can be difficult by cause of students' internal rejection of the need to study, unrealistic expectations about university life, low selfesteem. The previous place of residence may also impact on the student's adaptation.
In addition, there may be a contradiction between the intellectual, creative, personal capabilities of the student, on the one hand, and the possibilities of its realization provided by the educational institution, on the other. These opportunities are sometimes limited, and may be associated with significant organizational, financial or psychological complications.

From the previously outlined facts, it seems obvious that all freshmen are adapting to the new learning conditions in higher education institution, but the time limits of adaptation, the complexity of this process are not similar.

\section{Research Question}

Does rural origin of students influence their further academic, social and emotional adaptation to the changed learning and living environment?

The relevance of this problem can be explained by certain aspects: first, the need to ensure equal and high quality education in higher education institutions for all students, regardless of their origin; secondly, the need to find solutions for optimization and mitigation of the adaptation processes of rural youth in the student community.

The purpose of the article is to summarize the features of school education 
in rural areas in Ukraine and to determine their potential impact on students' academic and socio-psychological adaptation to a new learning and living environment.

\section{Literature review}

Analysis of scientific literature indicates that many scholars pay attention to the issue of students' adaptation to the changed conditions during their study in higher education institutions. Difficulties of the initial stage of study and factors influencing the process of adaptation of students are revealed in their scientific works by Al-Mahrooqi, \& Denman, \& Ateeq (2015), Elias, Mahyuddin, \& Uli (2009), Zdanevych (2011) etc.

The problem of adapting rural youth to the urban community requires a comprehensive and diverse analysis. It has been in the focus of attention of such scholars as Aurel Ion Clinciu (2013), Aylesworth, \& Bloom (1976), Maples (2000), Peters (1990) etc.

Nonetheless, despite the relevance of the issue, there has still been a lack of psychological and pedagogical studies that investigate adaptation of students from rural area to new living conditions, values and social norms of the new community.

Adaptation is a component of the mechanism of socialization, which occurs as a set of adjustments of a person to different life situations, during which social experience is accumulated and social norms and values are absorbed.

Zdanevych (2011) defines the process of students' adaptation as formation of a new attitude to profession; assimilation of new educational forms, assessments, methods and techniques of independent work, adjustment to a new type of educational team, its customs, traditions, new types of scientific activity, new living conditions, student culture and new forms use of leisure.

In addition, researchers Chyhryn (2006), Kaleeva (2002), Peters (1990) claim that the students of rural origin studying in cities often feel constrained and that they are not "fully accepted" in their new environments and are likely to experience some forms of social and emotional pressure.

To explore the factors that may influence adjustment of Ukrainian firstyear students of rural origin, this study provides analysis of the features of rural school education (on the example of Ukrainian rural schools).

\section{A small number of students per class}

A significant factor that determines the specificity of the educational process in a rural school is a small number of school 
children in classes, which has both positive and negative consequences. The average class fill rate in rural schools in Ukraine is 16.6. The highest figure is in the Autonomous Republic of Crimea - 21.2 and the lowest is in Chernihiv region - 12.8 (Education in Ukraine: basic indicators. Information and statistical bulletin, 2018).

In classes with small number of students, there are sometimes no leaders and no students with high level of learning ability and a desire for learning. Due to this, the learning process is impoverished, lack of high emotional mood has a negative impact on students' performance. Some well-established forms of education and training in urban schools are becoming ineffective in rural schools and do not allow good results.

Teachers working in rural schools face difficulties in choosing the optimum pace of study, the volume and logic of considering the course material, forms and methods of work. All this can negatively affect the cognitive interests of students, and as a consequence - the effectiveness of the entire educational process.

The small number of children in the class impairs communication, the students' interest in conversation disappears, and boredom arises. Communicative skills of each child depend largely on the social environment, which in many cases is impoverished in rural areas. The small number of students in the classroom who are constantly interacting impairs their speech, slows the broadening of their horizons, narrows the scope of everyday interests, and life experience is slower to accumulate. This is most evident in the delay in developing the ability to clearly express thoughts, and impairs the memorization of the content of the material (Kaleeva, 2002).

Educational activity of students is constantly under the control of a teacher. Along with the benefits of such learning, school children are often in a stress throughout the schooldays. This factor can negatively affect the depth of knowledge and desire to further learning.

\section{Poor material and technical condition}

Undoubtedly, the brake factor for rural education is the lack of adequate funding, weakness of the material base, demographic features, insufficient staffing of small schools, remoteness of most villages from administrative centers (Prokopiv, 2014). Rural schools often lack textbooks, visual aids, sports equipment and modern educational tools.

According to the Ministry of Education and Science of Ukraine, 11089 rural schools have central heating or their own boiler room, water supply - 10791 
(including hot water - 5358); dining room or hot buffet - 11612 (723170 seats), gym -8578 , educational site -6139 . There is still the lack of qualified teachers and technical equipment: in 2012, only $57.39 \%$ of rural schools were connected to the Internet (Educational reform: results and prospects. Information-analytical collection, 2019), although internet access at schools reduces the impact of the geographical distance factor and digital inequality by overcoming the learning gap of rural and urban school students (National Human Development Report "Ukraine: Towards Social Inclusion", 2011).

\section{Limited opportunities for students' creative self-realization and insufficient team work experience}

Adaptation is a prerequisite for social activity of a student and an indicator of the level of its development. An important factor influencing the adaptation process is living environment. The low availability of cultural objects in rural areas and the problems of transport links with district center reduce opportunities for creative self-realization of school children. During 1990-2011, the number of libraries decreased by 4,000. Their base is deteriorating, they need repair, almost all of them are not heated. Books and periodicals are not renewed. At the same time, the rural library (even in its present state) remains the only free information and cultural center of the modern village.

According to the sociological study "Attitudes of Ukrainian youth towards healthy lifestyles" (2010), 33\% of rural youth lack cultural institutions in their locality, $16 \%$ of villagers say that such institutions are too far away (A sociological study "Attitudes of Ukrainian youth towards healthy lifestyles", 2010). This means the inability to meet cultural needs and active leisure activities, which leads to an increase in the level of socially negative phenomena (adolescence drunkenness, usage of psychoactive substances, asocial behavior, etc.) (p. 953, Young people under conditions of Independence of Ukraine (1991-2011 years), 2011).

In rural schools, the opportunities for creative development of children are worse because of the lack of school theaters, creative associations and the like, which makes it impossible to carry out quality work with gifted students of rural schools. The child learns not only from the teacher, school environment is also the important teacher, since it teaches the children to communicate, enables them to learn different behavior patterns and different social roles. 
The older the child is, the more important is the team. The child who joins larger number of teams has more advanced communication skills, developed ability to analyze one's own actions and actions of other people, can easily adapt to the changing environment, find a common language with peers etc. Unfortunately, students enrolled in rural school, often lack this experience.

\section{Low motivation of students to study}

In the countryside, the specificity of the labor market has changed. If, in the recent past, agricultural production required low-skilled workers who performed a considerable amount of heavy manual labor, the current socio-economic and political transformations in the rural society led to changes in the requirements for the qualification of workers. Modern agricultural machinery, automation of production processes require highly skilled workers, which places education among the top priorities of life and development of rural society. Therefore, a prospective rural school should prepare its graduates for further education at higher education institutions, providing highly qualified personnel for the development of both agricultural production and the sociocultural sphere of a village (Shyyan, 2013).
However, there are numerous cases of rudeness of school children and their parents towards village teachers. The reluctance to learn leads to a hostile attitude towards teachers and school as a whole, the authority of a teacher is diminished, and the education itself loses its importance. Rural children generally do not see the prospect of admission to higher education. They see their parents' unskilled work; most children work physically and supplement their family budget. The lack of a positive learning motive is the reason for the poor performance of rural students.

\section{Methodology \\ Research sample}

To understand whether students from rural areas face additional challenges adjusting to changed living conditions and learning environment while studying in universities compared to students from urban and suburban areas, the two-stage diagnostic study of 270 first-year students of the Bohdan Khmelnytsky National University at Cherkasy, Ukraine, has been conducted. As this study aimed to investigate issues related to the process of adaptation, a sample was drawn from firstyear students in academic year 2018/2019.

\section{Instrument}


The authors' "Questionnaire for monitoring adaptation of the first-year students" (Annex) for factual data was employed. Areas examined as potentially effecting first-year students' adaptation include living conditions, expectations before and after entering university, selfesteem, the academic, social and emotional demands of their new roles as university students, stress, and the desire to leave university before obtaining a degree. The obtained data were subjected to statistical analysis, followed by qualitative interpretation and meaningful generalization.

\section{Demographic profile of the participants}

Among the respondents: students from rural areas (together with people from urban settlements) make up $72.2 \%$. The rest $(27.8 \%)$ are locals or came from small cities (with a population of up to 100,000 ).

150 respondents are students living in a hostel; 45 people rent an apartment or room; 75 people live at home with their parents. That is, $72.2 \%$ of the students had to change their place of residence for study.

However, for $75.7 \%$ of them the relocation was limited to the borders of the area where they had previously resided (probably the relocation to the regional center). $18 \%$ went to study in another area, but nearby, in the same region. A rather small number of students (6.3\%) risked going to study in other regions of the country.

\section{Data analysis \\ General expectations}

By means of conversation and content analysis of the received verbal production, typical expectations and attitudes of freshmen on university education were revealed. Generalized and most common expectations are as follows:

- the university is a "temple of science" in which a lot of time is required for study;

- tight control over discipline and learning, in particular, students expected: systematic supervision and tutelage from teachers and supervisors; detailed explanations of behavior at lectures and seminars;

- expectations of peers, classmates: familiarity will be organized from the outside; fast achievement of the desired status in the group;

- expectations for structuring extracurricular time: freshmen considered that teachers would organize extracurricular preparation for classes and even leisure.

A questionnaire method was used to diagnose freshman adaptation problems. The questionnaire consisted of blocks of 
questions aimed at identifying: the experience of adaptive stress; features of learning motivation; strategies of educational activity; orientation in the situation of study at university; attitudes, ideas, expectations about studying at the university.

\section{Self-assessment of the degree of adaptation}

The self-report indicators of the degree of adaptation of freshmen by the end of the second semester are as follows. $38.6 \%$ of the dormitory respondents said that the process of adaptation was easy for them, but $62 \%$ of respondents still have difficulty adjusting.

About $72 \%$ of students who have not changed their living conditions (living with their parents' families) have adapted to the new conditions quickly, and for $48 \%$ this process is not easy enough.

For those renting an apartment (alone or with friends), only $34.5 \%$ of respondents were easily accustomed to the new conditions, and $65.5 \%$ experienced some difficulties.

Thus, the process of adaptation was easy for $39 \%$ of students, while $61 \%$ of respondents emphasize the complexity of the process of getting used to the new conditions, and some of them have not yet fully adapted. A considerable number of freshmen - 58\% - feel stressed, some isolation and are quickly tired. This probably indicates that they have to make a lot of learning efforts. However, these efforts are not always effective, because many first-year students do not have enough time to prepare for seminars, and the lecture material is not always understood. At the same time, their expectations (regarding the teachers, their group mates) are false. It is difficult for most first-year students to absorb the full amount of educational information within the set deadlines.

Among the problems that cause adaptation difficulties, the students indicated the following:

- personal: false, inadequate expectations and illusions about the chosen higher education institution and/or specialty; uncertainty of one's life plans and goals; uncertainty of one's own learning strategy $-51.4 \%$;

- educational: change of the daily routine; sudden changes in the schedule; unexpected tests and exams; new methods and forms of educational and scientific work; high requirements for students during tests and exams; frequency of control of students' knowledge; necessity of writing large abstracts in a short period; credit-module system of training $-56.3 \%$; 
- living conditions: absence of hot water; sudden termination of water supply for several days; inability of distribution of funds and/or responsibilities among roommates; inconvenience of living conditions; unfavorable conditions for learning; accommodation of six to seven people in a room; inability to use gas stoves; settling in a room with undergrads; dirty audiences; poor lighting; cold rooms $-45.2 \%$;

$$
\text { - psychological: missing }
$$

home and family; attitude of teachers and peers; fear of exam failure and/or deprivation of scholarship; unusual independence; novelty of the big city and peculiarities of life in new, completely changed conditions $-75,3 \%$;

- communicative: changes in the surrounding people; unknown norms of behavior in the student collective; mode of activity; style of interpersonal relations in the group, at the faculty; communication problems with classmates and/or teachers $66.7 \%$;

- $\quad$ related to the relationships in the group: selfishness, individualism of classmates; disputes, unfriendly relations with teachers; arrogance, superiority in the attitude of classmates; inability to find a common language with classmates; the need to respond publicly; the unfairness of teachers in assessing students' knowledge; self-confidence of individual classmates $67,1 \%$.

The revealed problems put a great strain on the nervous system and change the character of adaptation process of the freshmen. The psychological unpreparedness of youth for the educational process in higher education institution can contribute to the gradual accumulation of intellectual, mental fatigue, diminish attention, memory, thought, will, etc.

At a later stage of the study, we conducted a Taylor Manifest Anxiety Scale questionnaire (1953) for this sample to measure anxiety levels, consisting of 50 statements. To continue the study of emotional states, a depression test scale was applied, designed for differential diagnosis of depression and states close to depression. The results of this test indicate that the vast majority of students experience mild depression of situational or neurotic genesis (figure 1). 
Figure 1 - Levels of anxiety of the first-year students (in \%).

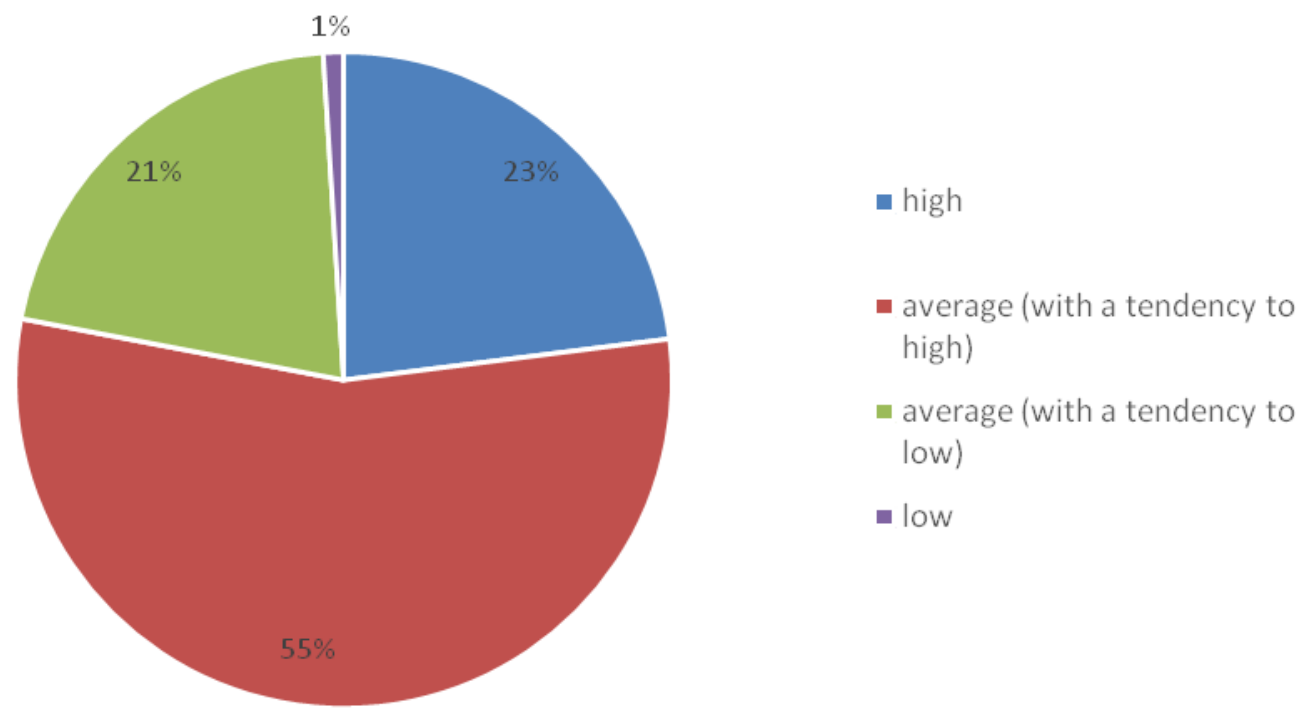

Source: author's calculations based on the conducted survey.

The conducted research of the students' adaptation process reveals that the latter is affected by certain difficulties,

\section{Practical applications}

which are a set of conditions or circumstances, which determine the level,

Following the presented findings, the pace, stability and outcome of student's adaptation. Knowledge and analysis of these difficulties is a prerequisite for managing adaptation processes.

Along with the academic adaptation experienced by all first-year students, it is important to emphasize the social and psychological aspect of it, related to the acquisition of new social norms by students of rural origin, the establishment and maintenance of a certain social status in the urban environment and the new community. researcher Chikina (2009) sees the optimization of the rural students' adaptation in the development and implementation of special courses or electives on the formation of the freshmen's readiness to study at a higher educational institution, as well as the introduction of additional disciplines.

To this end, psychologists, counselors and higher education executives should understand the students' adaptation problems; study the real needs of students; conduct confidential conversations with students that would allow them to express 
their experiences and subsequently to cope with them.

It is advisable to:

- conduct surveys of students' mood, reasons their dissatisfaction;

- conduct one-on-one interviews with parents for a deep family study;

- organize educational activities aimed at behavioral correction sessions, consolidation of the student's selfconfidence, ability to naturally behave among others, train manifestations of student's will in different life situations, promote students' self-esteem and develop the qualities necessary for fast adaptation to the new learning and living environment;

- carry out testing in order to study the personal characteristics of students.

Obviously, not all first-year students of rural origin need psychological help. With sufficient social mobility and the ability to use one's own internal resource, one can constructively resolve conflicts and successfully adapt to the new learning environment. However, there is a large group of young people who need, if not psychological help, at least support in the difficult life situation that may result from migration. In line with all aforementioned, development of recommendations for the organization of pedagogical process to reduce the intensity of adaptation processes of rural youth is necessary.

We assume, there are several directions of social and psychological support for students of rural origin:

- educational and psychological work with rural school children, directed at awareness of own resources and plans, optimization of life tasks and possibilities of their realization, awareness of positive and negative features of both rural and urban life; conscious weighing and reasonable choice of one's life path;

- psychological support to rural youth who have come to the city to receive education, regardless of whether they intend to stay in the city forever or plan to return to the village.

\section{Work with rural high school students}

Often, the choice of rural high school seniors to migrate to the city is not based on their own thinking, but on the model or guidance of significant adults and peers. There is a deep conviction among the rural population that the city has comfortable living conditions, a lot of opportunities and can significantly change the way and quality of life. According to such convictions, the fact of living in the city itself already provides with comfortable conditions, good work, inexhaustible opportunities, and the migration of 
villagers to the city is seen as a kind of success and achievement. At the same time, it is absolutely irrelevant how true the situation is to their ideas about life in the city. This attitude of the rural population, firstly, determines the active relocation of the younger generation to the city, and secondly, it reduces, and often makes it impossible for the migrant to return to the village, since such a fact will be seen with misunderstanding, and sometimes with condemnation.

The results of our study demonstrate that rural high school students have a hypertrophied view of the benefits of the city as a desired place of residence and job search. They often obviously overestimate the opportunities that the urban environment and urban lifestyle can provide them. Given that the city does not always live up to the expectations of rural migrant youth, not everyone is able to realize their full potential, such a situation can only exacerbate a sense of dissatisfaction and inner discomfort.

In this context, there is a need to form an adequate image of urban and rural lifestyles, their advantages and disadvantages, and development of socialpsychological training helping rural high school students find their own place in society, and form a mature social identity.

\section{Work with students of rural origin}

It is important to emphasize that the most active migration of rural population to the city is at the age of 15-24 years (Chyhryn, 2006). Consequently, an important and largest group of rural youth migrating to the city is rural youth seeking education.

Assuredly, admission to higher education is itself a crisis period and causes numerous adaptation challenges for students. For rural students, this situation is further complicated by the need to adapt to the new urban environment, to learn the rules and norms of life in the urban society, to master the urban lifestyle. Therefore, the process of adaptation of rural youth who have come to study in the city cannot be considered separately from the general processes of adaptation of students to new living conditions.

A special role in this process is played by the psychological service of the university, whose activity is aimed at providing conditions for full and harmonious individual development of students, developing their ability for selfdevelopment and self-education, promotion of their health, enhancing students' adaptive capacity and becoming a socially active personality.

The following directions of work of psychological service, counselors and 
educators in higher education institutions can be distinguished. The first one is to provide individual counseling for the student, including on problems of adaptation to the urban environment. It is important for the psychologist to have basic information on the course of adaptation processes, about possible difficulties, including those of the sociopsychological nature that a young person may encounter.

The second direction is the development and implementation of special training programs aimed at updating the social mobility of rural youth; activating their self-perception in the new environment, increasing their level of reflection and ability to set life goals in the light of the real social situation and to reach them; motivation for the development of spirituality, social, professional competence and selfactualization in general; adequacy of selfesteem; development of inner freedom, ability to defend one's own beliefs and to manage one's emotional state; develop a constructive attitude towards criticism etc.

The third important direction of work, in our opinion, is integration of individual classes into training programs, which would enhance friendly relations between rural and urban youth, help them to understand each other better, build constructive relationships, develop conflict-free behaviors; performing correction in communication disorders, adverse forms of emotional response and behavior, conflict relationships etc.

\section{Conclusions}

The conducted research shows that the students' adaptation to the changed living and learning environment is a complex, multi-faceted and dynamic process, which requires a synergistic approach. The authors' mini-questionnaire revealed that $62 \%$ of the first-year students of rural origin from a local National University named after Bohdan Khmelnytsky University at Cherkasy have difficulties in adaptation. Six major categories of obstacles generating weak adaptation for students: personal, educational, living conditions, psychological, communicative, relationships in the group. Each of them, alone or in combination, can create serious adjustment problems which could lead to students' failure to complete their studies. Features of Ukrainian rural schools that may impact on the adaptation process are distinguished: small number of students in class; heterogeneity of classes in composition, level of cognitive interests; poor material and technical condition; limited opportunities for self-realization 
and insufficient team work experience; low motivation to study etc. Directions of work of psychological service, counselors and educators in higher education institutions are displayed: individual counseling for the student, development and implementation of special training programs, integration of individual classes into training programs.

\section{References}

Al-Mahrooqi, R., \& Denman, C. J., \& Ateeq, B. A. (2015). Adaptation and firstyear university students in the Sultanate of Oman. Issues in English education in the Arab world (pp.60-82). Publisher: Cambridge Scholars, Editors: R. AlMahrooqi, Christopher Denman.

A sociological study "Attitudes of Ukrainian youth towards healthy lifestyles". (2010). National Institute for Family and Youth Development, supported by UNICEF. Retrieved from: www.mzz.com.ua [in Ukrainian].

Ackermann, M. E., \& Morrow, J. A. (2007-2008). A principal components analysis and validation of the Coping with the College Environment Scale (CWCES). Journal of College Student Retention, 9, 133-148. https://doi.org/10.2190/CS.9.2.a

Aurel Ion Clinciu (2013). Adaptation and Stress for the First Year University Students. Procedia - Social and Behavioral Sciences, 78, 718-722. https://doi.org/10.1016/j.sbspro.2013.04.38 $\underline{2}$.

Aylesworth, L. S., \& Bloom, B. L. (1976). College experience and problems of rural and small-town students. Journal of College Student Personnel, 17, 236-242
Chang, E. C., Sana, L. J., Riley, M. M., Thornburg, A. M., Zumberg, K. M., \& Edwards, M. C. (2007). Relation between problem-solving styles and psychological adjustment in young adults: Is stress a mediating variable? Personality and Individual Differences, 42, 135-144. https://doi.org/10.1016/j.paid.2006.06.011

Chikina, T. E. (2019). Freshman Adaptive Learning. Vyssheye obrazovaniye v Rossii, 6, 143-145 [in Russian].

Chyhryn, V. O. (2006). Rural youth: experience of complex sociological analysis: monograph. Melitopil [in Ukrainian].

Cole, G. J. (2019). Rural students: the next frontier for university recruiters. Keystone: Academic Solutions. Retrieved from: https://www.keystoneacademic.com/news/ rural-students-the-next-frontier-foruniversity-recruiters.

Education in Ukraine: basic indicators. Information and statistical bulletin. (2018). Ministry of Education and Science of Ukraine. Retrieved from: https://mon.gov.ua/storage/app/media/nova -ukrainska-shkola/1serpkonf-

informatsiyniy-byuleten.pdf

Ukrainian].

Educational reform: results and prospects. Information-analytical collection. (2019). Ministry of Education and Science of Ukraine. Retrieved from: https://mon.gov.ua/storage/app/media/Serp neva\%20conferentcia/2019/Institut-osvanalitiki.pdf [in Ukrainian].

Elias, H., Mahyuddin, R., \& Uli, J. (2009). Adjustment amongst first year students in a Malaysian university. European Journal of Social Sciences, 8(3), 494-505.

Janet A. T. (1953). A Personality Scale of Manifest Anxiety. Abnormal and Social 
Psych.,

$48(2)$,

285-290.

https://doi.org/10.1037/h0056264

Kaleeva, Zh. G. (2002). Rural School Concerns. Pedagogika, 5, 64-69 [in Russian].

Maples, M. R. (2000). Rural students' satisfaction with college environment: An ecological consideration. (Doctoral dissertation, The University of Iowa). Dissertation Abstracts International, 61(12), 4681. (UMI No. 9996133).

National Human Development Report "Ukraine: Towards Social Inclusion". United Nations Development Program in Ukraine 2011. Retrieved from: http://www.undp.org.ua/files/ua 95644NH DR_2011_Ukr.pdf.

Peters, D. (1990). Factors affecting institutional departure by rural freshman. Dissertation Abstracts International, 51(8), 2653. (UMI No. 9102126).

Prokopiv L. (2014). Modernization of small rural school: problems and prospects. Lyudynoznavchi studiyi, 29, 141-148 [in Ukrainian].

Rural Education. (2019). United States Department of Agriculture: Economic Research Service. Retrieved from: https://www.ers.usda.gov/topics/ruraleconomy-population/employmenteducation/rural-education

Rural Students in Higher Education. (2020). Postsecondary National Policy Institute. Retrieved from: https://pnpi.org/rural-students-in-highereducation

Samohin, I. (2014). Demographic crisis and inequality in the Ukrainian school system: analysis of the new database "School Map of Ukraine". Retrieved from: https://www.cedos.org.ua/edustat/graph
Shyyan, N. I. (2013). Peculiarities of the educational process in the rural school. XX Karyshynski chytannia: materialy Mizhnarodnoi naukovo-praktychnoi konferentsii «Metodyka navchannia pryrodnychykh dystsyplin $u$ serednii ta vyshchii shkoli» (pp.379-382) [in Ukrainian].

Young people under conditions of Independence of Ukraine (1991-2011 years). (2011). In O. Belishev (Ed.). The annual report to the President of Ukraine, the Verkhovna Rada of Ukraine, the Cabinet of Ministers of Ukraine on the situation of youth in Ukraine (pp. 950953).

Zdanevych, L. V. (2011). Some aspects of student disadaptation in the process of learning. Pedahohichnyy dyskurs, 9, 125128 [in Ukrainian].

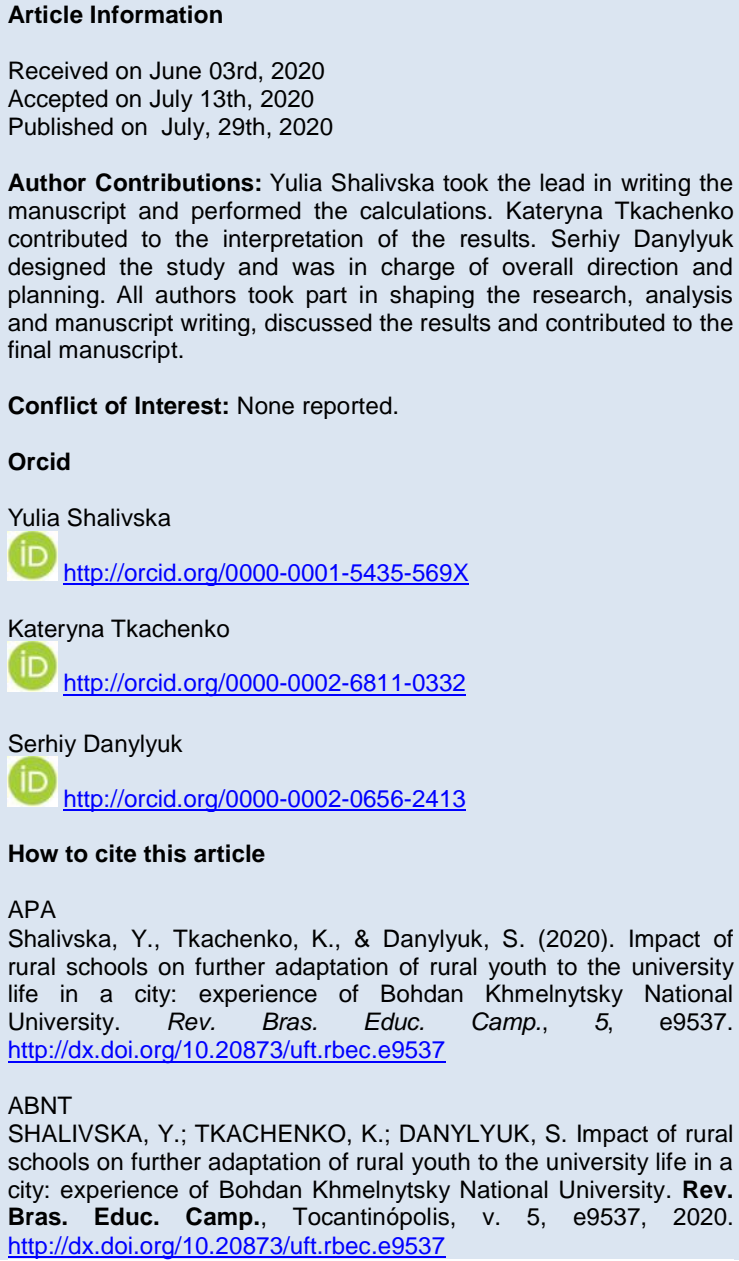

Author Contributions: Yulia Shalivska took the lead in writing the manuscript and performed the calculations. Kateryna Tkachenko contributed to the interpretation of the results. Serhiy Danylyuk designed the study and was in charge of overall direction and planning. All authors took part in shaping the research, analysis and manuscript writing, discussed the results and contributed to the final manuscript.

Conflict of Interest: None reported.

Orcid

Yulia Shalivska

(iD) http://orcid.org/0000-0001-5435-569X

Kateryna Tkachenko

iD http://orcid.org/0000-0002-6811-0332

Serhiy Danylyuk

iD http://orcid.org/0000-0002-0656-2413

How to cite this article

APA

Shalivska, Y., Tkachenko, K., \& Danylyuk, S. (2020). Impact of rural schools on further adaptation of rural youth to the university life in a city: experience of Bohdan Khmelnytsky National University. Rev. Bras. Educ. Camp., 5, e9537. http://dx.doi.org/10.20873/uft.rbec.e9537

ABNT

SHALIVSKA, Y.; TKACHENKO, K.; DANYLYUK, S. Impact of rural schools on further adaptation of rural youth to the university life in a city: experience of Bohdan Khmelnytsky National University. Rev. Bras. Educ. Camp., Tocantinópolis, v. 5, e9537, 2020. http://dx.doi.org/10.20873/uft.rbec.e9537 


\section{Annex}

"Questionnaire for monitoring adaptation of the first-year students"

Dear students! It is very important for us to know how you feel inside Bohdan Khmelnytsky

National University at Cherkasy. Please spend a few minutes to honestly answer the questions.

\section{WE GUARANTEE ANONYMITY!}

1. Do you like studying at university?
a. yes
b. no
c. not yet decided
d. your answer

2. What made you decide to get higher education?
a. desire to become a highly educated specialist, a professional in the chosen field
b. desire to become a cultured person,
c. intention to develop abilities and skills
d. desire to live an interesting student life
e. awareness of the fact that it is difficult to achieve anything in life without diploma
f. other reason

3. Why did you choose our university?
a. interest in the future profession
b. wanted to study in a big city
c. desire of parents
d. advice from friends
e. other variant (please, specify)

4. Are you satisfied with your learning outcomes?
a. yes
b. no
c. $50 / 50$

5. What prevents you from achieving better results and academic success?
a. laziness
b. lack of literature
c. low internet speed/lack of internet
d. unwillingness to learn
e. relationships in the group
f. other (please, specify)

6. What was the most difficult for you at the beginning of your study at the university?
a. to adapt to the requirements of teachers
b. to adjust to a new class
c. to master a new educational system
d. other (please, specify)

7. What unusual (new) things did you face when you became a student? (several answer options are allowed) 

a. organization of the learning process, daily number of classes
b. large amount of independent work
c. features of dormitory life
d. new norms of student communication
e. features of independent living apart from family
f. other (please, specify)

8. What do you value most in teachers?
a. ability to teach the material well
b. sense of humor and good mood
c. knowledge
d. fairness of assessment
e. other (please, specify)

9. What are the relationships in your academisc group?
a. friendly
b. unfriendly
c. hostile
d. other (please, specify)

10. Did you manage to establish friendly relations with all your groupmates?
a. yes
b. mostly
c. no
d. other (please, specify)

11. If you have learning difficulties, what are they related to? (multiple choice is allowed)
a. difficult content of academic disciplines
b. lack of school preparation, insufficient previously acquired knowledge
c. conflicts (misunderstandings) with teachers
d. conflicts (misunderstandings) with groupmates
e. no problems with learning
f. other (please, specify)

12. Where do you live?
a. at home
b. rent an apartment
c. in dormitory
d. other (please, specify)

13. Are you satisfied with the living conditions? If not - indicate the reason
a. yes
b. no

14. What difficulties have you encountered in the dormitory? (multiple choice is allowed)
a. I do not live in a dormitory
b. I do not know how to save money, plan expenses
c. the need to live in a room with other students
d. it is difficult to perform tasks and prepare for classes independently
e. I spend a lot of time cooking, cleaning etc. 
f. I miss my family very much

g. unfriendly roommates

h. other (please, specify)

15. Did you experience any form of bullying in the university from
a. groupmates
b. senior students
c. roommates
d. faculty members
e. there were no cases of violence
f. other (please, specify)

16. What, in your opinion, hinders the process of adaptation to the conditions of university education?
a. personal disorganization and laziness
b. tension, fatigue from classes
c. insufficient interest in the chosen specialty
d. lack of time management skills
e. weak previous educational base
f. misunderstanding on the part of teachers and excessive demands
g. other (please, specify)

17. Do you experience any of the following emotional states while studying in the university?
a. inner tension
b. self-doubt
c. concentrating difficulty
d. increase anxiety
e. sleep disorders
f. comparing yourself to others
g. other (please, specify)

18. What ways of solving educational problems do you choose?
a. independently look for rational ways to solve problem situations;
b. I'm waiting for everything to settle down, I'm not doing anything
c. discuss problems with groupmates
d. discuss problems with friends
e. ask for help from faculty members
f. ask for help from a tutor
g. ask for help from parents

19. Do relationships in the group you study in affect the outcome of your learning activities?
a. yes
b. no
c. did not pay attention
d. other (please, specify)

20. How much time a day do you spend preparing for classes? 

a. 2-3 hours
b. 4 hours and more
c. Less than 2 hours
d. I don't prepare for classes

21 . What problems worry you the most?
a. related to learning
b. related to living conditions
c. relationships with family
d. relationships with groupmates
e. relationships with faculty members
f. other (please, specify)

22. Continue the sentence "University is ....."

23. Continue the sentence "What I like most in university is..."

24. Continue the sentence "What I don't like in university is..." 